\title{
Respiratory allergy to Blomia tropicalis: Immune response in four syngeneic mouse strains and assessment of a low allergen-dose, short-term experimental model
}

Tiana Baqueiro 1,2, Momtchilo Russo33, Virgínia MG Silva1,4, Thayna Meirelles4, Pablo RS Oliveira4, Eliane Gomes³, Renato Barboza $3{ }^{3}$ Ana T Cerqueira-Lima', Camila A Figueiredo', Lain Pontes-de-Carvalho 4 and Neuza M AlcântaraNeves*1

\begin{abstract}
Background: The dust mite Blomia tropicalis is an important source of aeroallergens in tropical areas. Although a mouse model for B. tropicalis extract (BtE)-induced asthma has been described, no study comparing different mouse strains in this asthma model has been reported. The relevance and reproducibility of experimental animal models of allergy depends on the genetic background of the animal, the molecular composition of the allergen and the experimental protocol.
\end{abstract}

Objectives: This work had two objectives. The first was to study the anti-B. tropicalis allergic responses in different mouse strains using a short-term model of respiratory allergy to BtE. This study included the comparison of the allergic responses elicited by $B t E$ with those elicited by ovalbumin in mice of the strain that responded better to $B t E$ sensitization. The second objective was to investigate whether the best responder mouse strain could be used in an experimental model of allergy employing relatively low BtE doses.

Methods: Groups of mice of four different syngeneic strains were sensitized subcutaneously with $100 \mu \mathrm{g}$ of $B t E$ on days 0 and 7 and challenged four times intranasally, at days $8,10,12$, and 14, with $10 \mu \mathrm{g}$ of BtE. A/J mice, that were the best responders to $B t E$ sensitization, were used to compare the $B$. tropicalis-specific asthma experimental model with the conventional experimental model of ovalbumin (OVA)-specific asthma. A/J mice were also sensitized with a lower dose of BtE.

Results: Mice of all strains had lung inflammatory-cell infiltration and increased levels of anti-BtE IgE antibodies, but these responses were significantly more intense in $\mathrm{A} / \mathrm{J}$ mice than in CBA/J, BALB/C or C57BL/6J mice. Immunization of $A / J$ mice with $B t E$ induced a more intense airway eosinophil influx, higher levels of total IgE, similar airway hyperreactivity to methacholine but less intense mucous production, and lower levels of specific $\lg E$, $\lg G 1$ and $\lg G 2$ antibodies than sensitization with OVA. Finally, immunization with a relatively low BtE dose $(10 \mu \mathrm{g}$ per subcutaneous injection per mouse) was able to sensitize A/J mice, which were the best responders to high-dose BtE immunization, for the development of allergy-associated immune and lung inflammatory responses.

Conclusions: The described short-term model of BtE-induced allergic lung disease is reproducible in different syngeneic mouse strains, and mice of the A/J strain was the most responsive to it. In addition, it was shown that OVA and $B t E$ induce quantitatively different immune responses in $A / J$ mice and that the experimental model can be set up with low amounts of $B t E$.

\footnotetext{
*Correspondence: neuza@ufba.br

${ }^{1}$ Departamento de Biointeração, Instituto de Ciências da Saúde, Universidade Federal da Bahia, Av. Reitor Miguel Calmon, Sem nº. Canela, Salvador, Bahia, CEP 40110902, Brasil

Full list of author information is available at the end of the article
} 


\section{Introduction}

Exposure to house dust mite allergens is recognized as the most important risk factor for the development of allergic diseases [1-3]. Among the mites, Dermatophagoides pteronyssinus and Blomia tropicalis are the main sources of allergens in sub-tropical and tropical regions of the world [4-6]. High frequencies of positivity to $B$. tropicalis antigens in skin prick tests have been described in asthma and rhinitis patients, such as $68.1 \%$ in Cuba [7], 91.6\% in Venezuela [8], 73.3\% in Taiwan [9] and 95.0\% in São Paulo, Brazil [10]. There is evidence that allergens from B. tropicalis are distinct from, and bear only low to moderate cross-reactivity to allergens from Dermatophagoides sp. [11]. For instance, antibodies from allergic patients against the main $B$. tropicalis allergens (proteins of 14.3 and $27.3 \mathrm{kDa}$ ) do not inhibit the binding of anti- $D$. pteronyssinus antibodies to $D$. pteronyssinus antigens $[4,9,11]$. Thus, sensitization to $B$. tropicalis allergens is considered an independent and important cause of allergy $[4,8]$. These findings justify studies on speciesspecific diagnosis and immunotherapy for $B$. tropicalis allergy in regions where this species occurs alone or concomitantly with $D$. pteronyssinus.

Animal models that mimic the immunological and pulmonary inflammation features observed in human asthma are important tools to dissect the basic cellular and molecular mechanisms involved in the initiation and control of allergy [12]. Conventional models of allergic asthma rely on the sensitization of experimental animals to ovalbumin (OVA). However, in humans, most cases of asthma are due to aeroallergens, and OVA-induced asthma is far from being a common event. Thus, experimental asthma models using common allergens might be more relevant tools to the study of human asthma [13]. Despite the bulk of work done in humans on mite-specific allergy, data on allergic responses to $B$. tropicalis antigens in murine models are scarce [14-16]. These works were carried out using single $(\mathrm{A} / \mathrm{Sn}$ or $\mathrm{BALB} / \mathrm{c})$ mouse strains, and, to the best of our knowledge, no work comparing the allergic response to $B$. tropicalis antigens in different mouse strains has been done so far. Experimental data indicate that inbred mouse strains differ in their ability to mount an allergen-induced asthmatic response $[17,18]$. Mice of some strains develop an intense airway hyperreactivity, eosinophilia and IgE production, while others fail to produce allergic responses [18].

The first objective of the present work was to study the murine allergic response to B. tropicalis using a shortterm immunization protocol. The following parameters were used to measure the immune response in mice of four inbred strains (CBA/J, BALB/c, A/J and C57Bl/6): (i) the total number of leukocytes and eosinophils in the bronchoalveolar lavage fluid (BALF); (ii) the concentration of IL-4 and IL-13 cytokines and eosinophil peroxi- dase (EPO) in the BALF; (iii) the serum levels of anti- $B$. tropicalis IgE antibodies. BtE-immunized mice of the most responsive strain (A/J strain) were then assessed for the presence of intra-bronchial mucous, airway hyperresponsiveness (AHR) to methacholine challenge and inflammatory cell infiltration in lung tissue. These mice were also compared with OVA-immunized $\mathrm{A} / \mathrm{J}$ mice in all the immunological and inflammatory parameters that were mentioned above. As a second objective of the present work, mice of the best-responder strain were immunized with relatively low doses of $B t \mathrm{E}$ aiming at obtaining a low allergen-dose, short term murine model of respiratory allergy to B. tropicalis that reproduced many immunological and pathological features of the human disease.

\section{Materials and methods \\ Animals}

Eight to 10 week-old $\mathrm{CBA} / \mathrm{J}, \mathrm{BALB} / \mathrm{c}, \mathrm{A} / \mathrm{J}$ and $\mathrm{C} 57 \mathrm{BL} / 6$ male mice, and 3 to 4 month-old Wistar rats, were bred and maintained at the animal houses of the Gonçalo Moniz Research Center, Oswaldo Cruz Foundation, Salvador, Brazil, and of the Biomedical Sciences Institute, University of São Paulo, São Paulo, Brazil. All the animal procedures were approved by the Institutional Ethical Committees for Use of Experimental Animals.

\section{Blomia tropicalis extract}

B. tropicalis house dust mites were collected from bed dust in Salvador, Brazil, cloned and cultured with a powdered fish food medium (Spirulina, Alcon Gold, São Paulo, Brazil), and dry yeast (Fermipan, São Paulo, Brazil), at $25^{\circ} \mathrm{C}$ and $75 \%$ humidity. The mites were purified from the medium by flotation on a $5 \mathrm{M}$ sodium chloride solution, followed by several washings by filtration, using a $100 \mu \mathrm{m}$ pore size polystyrene sieve and endotoxin-free distilled water. The washings were carried out until no food residues could be seen under microscopy. The mites were lysed in $0.15 \mathrm{M}$ phosphate-buffered saline, $\mathrm{pH} 7.4$ (PBS), in a blender (Waring Commercial, Torrington, Connecticut, USA). Lipids from the lysate were extracted and discarded by five or six ether extractions. The protein content of the aqueous extract was determined by the Folin reagent method, described by Lowry and collaborators [19], and was subsequently stored at $-70^{\circ} \mathrm{C}$ until use. The amount $B t \mathrm{E}$ used in the experiments was standardized by measuring its content in B. tropicalis Blo t 5 allergen, measured by a commercially available capture ELISA kit (INDOOR Biotechnologies, Charlottesville, VI, USA). All used batches contained 30-40 ng of this allergen per $\mu \mathrm{g}$ of protein.

\section{Sensitization protocol}

Groups of mice from different mouse strains were sensitized to $B t$ E by subcutaneous injections of $100 \mu \mathrm{g}$ or $10 \mu \mathrm{g}$ 
of $B t \mathrm{E}$ adsorbed to $1.6 \mathrm{mg}$ of alum $\left[\mathrm{Al}(\mathrm{OH})_{3}\right]$ gel (Sigma Chemical Co., St. Louis, MO, USA) on days 0 and 7 and challenged intranasally with $10 \mu \mathrm{g}$ of $B t \mathrm{E}$ in $50 \mu \mathrm{l}$ of saline on days 8, 10, 12 and 14. Four different batches of $B t \mathrm{E}$ were used in different experiments. Control groups received only alum and were challenged with saline or with $B t \mathrm{E}$. In addition, groups of $\mathrm{A} / \mathrm{J}$ mice were injected with $100 \mu \mathrm{g}$ of OVA (Sigma Chemical Co., St. Louis, MO, USA) adsorbed to alum and challenged with $50 \mu \mathrm{L}$ of saline containing $10 \mu \mathrm{g}$ of OVA, as described above for the $B t \mathrm{E}$. The mice were painlessly killed $24 \mathrm{~h}$ after the last allergen challenge.

\section{Blood collection}

Mice were deeply anesthetized by intraperitoneal injection with a solution containing ketamine (Ketamina Agener; União Química Farmacêutica Nacional S/A, São Paulo, Brazil) and chloral hydrate (Labsynth, São Paulo, Brazil) and blood samples from the retro orbital plexus were collected for serum antibody level determinations.

\section{Bronchoalveolar lavage fluid collection and cell counting}

The tracheas of the dead mice were cannulated and the BALF collected in $0.5 \mathrm{~mL}$ of PBS containing $1 \%$ of bovine serum albumin (Sigma Chemical Co., St. Louis, MO, USA; PBS-BSA). An aliquot of the BALF cells was washed three times by centrifugation, and the cell pellet resuspended in PBS-BSA. Total cell counts were carried out using a Neubauer chamber. Differential cell counts were performed in light microscopy, according to standard morphologic criteria, by counting, in a blinded fashion, 100 cells in cytospin preparations stained with Rosenfeld's stain. Following centrifugation $\left(400 \mathrm{~g}, 5 \mathrm{~min}, 4^{\circ} \mathrm{C}\right)$, supernatants of the BALF were collected and stored at $70^{\circ} \mathrm{C}$ for subsequent measurement of cytokine content and the pellets were used for the measurement of eosinophil peroxidase (EPO) activity.

\section{Eosinophil peroxidase activity in BALF}

The EPO activity present in BALF was determined by means of the colorimetric assay that was described by Strath et al. [20]. Briefly, the BALF was incubated with an erythrocyte-lysing buffer, consisting of $0.15 \mathrm{M} \mathrm{NH}_{4} \mathrm{Cl}, 1$ $\mathrm{mM} \mathrm{KHCO}$ and $0.1 \mathrm{mM}$ EDTA, $\mathrm{pH}$ 7.4, and centrifuged. The cell pellets were resuspended in PBS and lysed by three successive freezing and/thawing procedures, and then assayed for peroxidase activity in 96-well microassay plates, in duplicates, using $6.6 \mathrm{mM} \mathrm{H}_{2} \mathrm{O}_{2}$ and $1.5 \mathrm{mM}$ orthophenylenodiamine (Merck, Whitehouse Station, NJ, USA).

\section{Cytokine assays}

The BALF supernatants were stored at $-70^{\circ} \mathrm{C}$ until used. IFN- $\gamma$ and IL-4, IL-10 and IL-13 concentration measure- ments were assayed in commercial ELISA kits according to manufacturer's instructions (Pharmingen, St. Diego, CA, USA). Sensitivities were $>5 \mathrm{pg} / \mathrm{mL}$ for IL-4, $>2 \mathrm{pg} /$ $\mathrm{mL}$ for IL-10, $>0.5 \mathrm{pg} / \mathrm{mL}$ for $\mathrm{IL}-13$ and $>0.03 \mathrm{ng} / \mathrm{mL}$ for INF- $\gamma$.

\section{Lung histology}

After the BALF collection, the lungs were perfused, via the heart right ventricle, to remove residual blood, immersed in 10\% phosphate-buffered formalin for $24 \mathrm{~h}$, followed by $70 \%$ ethanol, and embedded in paraffin. Tissues sections of $5-\mu \mathrm{m}$ were then stained with periodic acid-Schiff (PAS) for the evaluation of mucus production. A quantitative digital morphometric analysis was performed using the application program Metamorph 6.0 (Universal Images Corp. Downingtown, PA, USA). The circunference area of the bronchi in the PAS-stained area was electronically measured and the mucus index was determined by the following formula: Mucus index = (PAS-stained area/bronquial cross-section area) $\times 100$.

\section{Determination of airway responsiveness}

Airway responsiveness to increasing doses of inhaled methacholine $(3,6,12$ and $25 \mathrm{mg} / \mathrm{mL})$ in conscious unrestrained mice was determined using a single-chamber, whole-body plethysmograph (Buxco Electronics Inc., Wilmington, NC, USA), as previously described [21]. After each nebulization with methacholine, recordings were taken for $5 \mathrm{~min}$. Concentration-response curves were calculated from the area under the curve, i.e. the time integral of changes in airway resistance within 20 $\min [22]$.

\section{ELISA for immunoglobulin isotypes}

Serum anti-OVA or anti-BtE IgG1 and IgG2a antibodies were measured using OVA- or BtE-coated microtitre plates and biotin-conjugated anti-mouse IgG1 or antimouse IgG2a, respectively (Pharmingen, St. Diego, CA, USA), in conjunction with streptavidin-horseradish peroxidase, $\mathrm{H}_{2} \mathrm{O}_{2}$ and orthophenylenodiamine (Merck, Whitehouse Station, NJ, USA). Total IgE was detected using anti-mouse IgE-coated microtitre plates and biotinconjugated anti-mouse IgE (UNLB Southern Biotechnology Associates, Inc., Birmingham, AL, USA), in conjunction with streptavidin-horseradish peroxidase, $\mathrm{H}_{2} \mathrm{O}_{2}$ and orthophenylenodiamine. The antibody concentration was obtained by interpolation into a curve obtained by concomitantly assaying different concentrations of mouse IgE.

\section{Passive cutaneous anaphylaxis reaction (PCA)}

IgE antibody serum levels were estimated by PCA reaction, as described by Mota and Wong [23]. In brief, 0.05 $\mathrm{mL}$ volumes of double dilutions (1/4 to 1/512) of individual mouse serum samples were intradermically injected 
in the shaved dorsal regions of Wistar rats. After 48 hours, the rats received $2 \mathrm{mg}$ of $B t \mathrm{E}$ in the tail vein, diluted in $0.5 \mathrm{~mL}$ of saline containing $0.5 \mathrm{mg} / \mathrm{mL}$ of Evans blue (Sigma Chemical Co, St. Louis, MO, USA). The rats were painlessly killed $30 \mathrm{~min}$ later, and the reciprocal of the highest serum dilution to produce a blue spot with more than $5 \mathrm{~mm}$ of diameter was considered the PCA titer.

\section{Statistical analysis}

The normality of the data was determined using the Komogorov-Smirnov test. In order to verify differences among more than two mouse groups, the results were analyzed using the one-way ANOVA test and the Tukey's post test. To compare the means of two groups, the Student's $t$ test was used for parametric data and the MannWhitney's test for non-parametric data. All results were considered statistically significant when $\mathrm{p} \leq 0.05$.

\section{Results}

Cytokine, EPO and leukocyte concentrations in BALF, and IgE serum levels, in four strains of mice following sensitization and challenge with $B$. tropicalis extract

Groups of mice were sensitized subcutaneously with $B t \mathrm{E}$ co-adsorbed into alum on days 0 and 7, challenged intranasally with $B t E$ on days $8,10,12$ and 14 and studied $24 \mathrm{~h}$ later. Although the total cell counts in BALF were higher in sensitized $\mathrm{A} / \mathrm{J}$ mice than in the other sensitized mouse strains, the differences were not statistically significant ( $\mathrm{p}$ $>0.05$, ANOVA test; Figure $1 \mathrm{~A}$ ). Only in $\mathrm{A} / \mathrm{J}$ and $\mathrm{CBA} / \mathrm{J}$ mice these total cell counts differed significantly from their saline controls $(\mathrm{p}<0.05$; Tukey's test; Figure 1A). Eosinophil numbers increased in the BALF of all sensitized mouse strains, in relation to their saline control (Figure 1B; $\mathrm{p}<0.05$ for BALB/c and $\mathrm{p}<0.001$ for $\mathrm{A} / \mathrm{J}$, $\mathrm{CBA} / \mathrm{J}$ and $\mathrm{C} 57 \mathrm{Bl} / 6$; Tukey's test). No differences in numbers of macrophage, lymphocyte and neutrophils in the BALF were observed among the mice of all four strains ( $p$ $>0.05$, ANOVA; data not shown). EPO activity levels in BALF increased in all $B t$-sensitized and challenged mice and was higher in $\mathrm{A} / \mathrm{J}, \mathrm{CBA} / \mathrm{J}$ and $\mathrm{C} 57 \mathrm{Bl} / 6$ mice than in $\mathrm{BALB} / \mathrm{c}$ mice $(\mathrm{p}<0.0001, \mathrm{p}<0.001$, and $\mathrm{p}<0.01$, respectively; Tukey's test; Figure 1C). Mice from all four studied strains, sensitized and challenged with $B t E$ had higher levels of $B t \mathrm{E}$-specific IgE as revealed by PCA, than the alum- and saline-treated control mice $(\mathrm{p}<0.001$ for $\mathrm{A} / \mathrm{J}$, $\mathrm{p}<0.01$ for $\mathrm{CBA} / \mathrm{J}$, and $\mathrm{p}<0.05$ for $\mathrm{C} 57 \mathrm{Bl} / 6$ and $\mathrm{BALB} / \mathrm{c}$, Tukey's test; Figure 1D). The differences in IgE titers in $B t E$-sensitized and challenged mice in the four studied mouse strains were not statistically significant $(p>0.05$; ANOVA), although $\mathrm{A} / \mathrm{J}$ mice showed the highest titers, followed by the CBA/J, C57Bl/6 and BALB/c mice. IFN- $\gamma$ and IL-10 concentrations in the BALF from BtE-sensitized or saline-treated mice of all tested mouse strains were low, and no statistically significant differences were found among the studied groups and their negative controls (data not shown). The production of IL-4 in $B t E$ sensitized and challenged mice was higher in $\mathrm{A} / \mathrm{J}$ when compared with the other studied mouse strains (Tukey's test, $\mathrm{p}<0.05$; Figure $1 \mathrm{E}$ ); it was followed by the production in CBA/J mice ( $\mathrm{p}<0.01$, Tukey's test). BtE-sensitized and challenged $\mathrm{BALB} / \mathrm{c}$ or $\mathrm{C} 57 \mathrm{Bl} / 6$ mice produced low amounts of IL-4, which were similar to those produced by their saline-treated control groups ( $p>0.05$, Tukey's test; Figure 1E). IL-13 production was increased in $\mathrm{A} / \mathrm{J}$ and $\mathrm{C} 57 \mathrm{Bl} / 6$ sensitized mice in comparison with the corresponding control mice ( $\mathrm{p}<0.05$, Tukey's test; Figure 1F). Figure 1G shows that specific IgG1 was produced in all $B t \mathrm{E}$-sensitized mice and that its levels were statistically different from those of the control mice $(\mathrm{p}<0.001$ for $\mathrm{BALB} / \mathrm{C}, \mathrm{C} 57 \mathrm{Bl} / 6$, and $\mathrm{A} / \mathrm{J}$ mice, and $\mathrm{p}<0.05$ for $\mathrm{CBA} / \mathrm{J}$; Tukey's test).

Animals that were not subcutaneously immunized with $B t E$ (they received instead control injections of alum), and were subsequently challenged with $B t \mathrm{E}$, did not differ from control, non-immunized mice that were challenged with saline, in any of the studied parameters (data not shown).

\section{Comparison of sensitization to $\mathrm{BtE}$ with sensitization to OVA, and presence of AHR and intra-bronchial mucus in A/J mice}

Since A/J mice had more intense allergic responses, we selected this strain to make a comparison between the $B t \mathrm{E}$-induced asthma model with the classical OVAinduced asthma model. Animals sensitized and challenged with $B t E$ showed higher levels of total cells and eosinophils in the BALF than control mice ( $\mathrm{p}<0.001$, Figure $2 \mathrm{~A}$, and $\mathrm{p}<0.01$, Figure $2 \mathrm{~B}$; Tukey's test). OVA-sensitized mice also showed increased total cell $(\mathrm{p}<0.05$; Figure 2A; Tukey's test) and eosinophil counts $(\mathrm{p}<0.05$; Figure 2B; Tukey's test) in the BALF than the corresponding control, saline-treated animals. EPO activity in BALF was also higher in $B t E$-sensitized than in OVA-sensitized and control mice $(\mathrm{p}<0.05$ and $\mathrm{p}<0.001$, respectively; Tukey's test; Figure 2C). Sensitization with OVA ( $<<$ 0.001 , Tukey's test) and $B t \mathrm{E}(\mathrm{p}<0.01$, Tukey's test) induced AHR, as compared with control mice (Figure 2D). The mucus index was higher in mice sensitized with OVA than in mice sensitized with $B t E$ or in the mice of the saline-treated control group (Figure 3A; $\mathrm{p}<0.001$ and $\mathrm{p}<0.01$, respectively; ANOVA and Tukey's test). Representative micrographs of tissue sections of control, $B t \mathrm{E}$ or OVA-sensitized mice, stained with PAS, are shown respectively in Figure 3B, C and 3D. The effect of $B t E$ and OVA sensitizations on total IgE and specific antibodies levels are shown in Figure 4. Total IgE was higher in $B t \mathrm{E}$ sensitized animals (Figure 4A; $\mathrm{p}<0001$ ) and specific-IgE, 

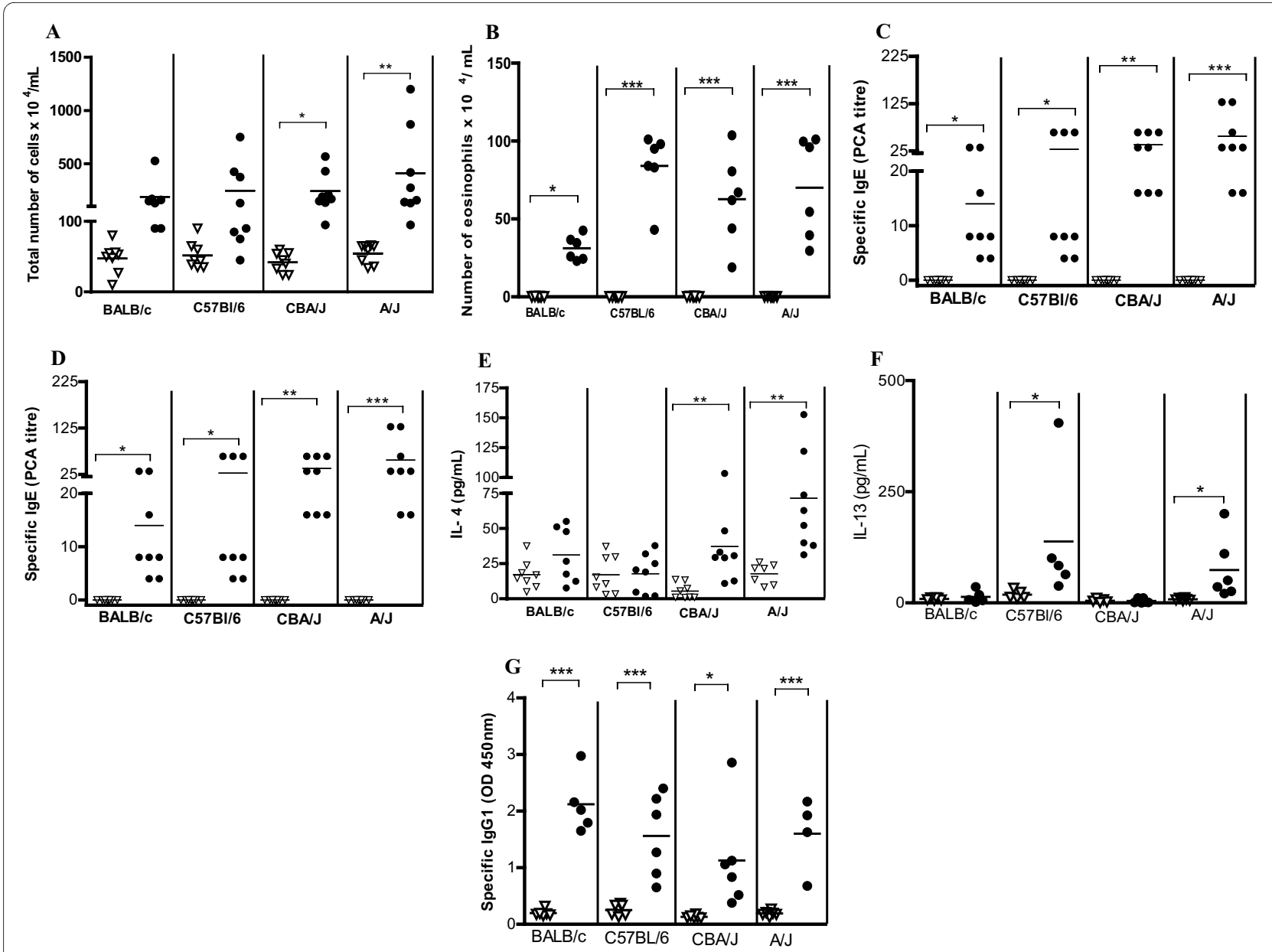

Figure 1 Immune response of $\mathrm{BALB} / \mathrm{C}, \mathrm{C} 57 \mathrm{BI} / 6, \mathrm{CBA} / \mathrm{J}$ and $\mathrm{A} / \mathrm{J}$ mice sensitized with Blomia tropicalis extract (closed symbols) or injected with saline (open symbols). (A) Total leukocyte numbers in the bronchoalveolar lavage fluid (BALF). (B) Eosinophil numbers in the BALF. (C) Level of eosinophil peroxidase (EPO) activity in BALF. (D) Anti-B. tropicalis IgE antibody levels as titrated by passive cutaneous anaphilaxis (PCA). (E) IL-4 concentration in BALF. (F) IL-13 concentration in BALF. (G) Anti-B. tropicalis IgG1 antibody levels in blood. Each symbol corresponds to the result obtained from an individual animal. This data is representative of three independent experiments. ${ }^{*} p<0.05,{ }^{* *} p<0.01,{ }^{* * *} \mathrm{P}<0.001$; ANOVA and Tukey's test. $P>0.05$ is not represented.

IgG2a and IgG1 antibodies were higher in OVA-sensitized group (Figure 4B-D; $\mathrm{p}<0.05$, Tukey's test).

\section{Evaluation of a low-dose B. tropicalis extract protocol and lung inflammatory infiltration in $\mathrm{A} / \mathrm{J}$ mice}

After the observation that $\mathrm{A} / \mathrm{J}$ was the best mouse strain for $B t \mathrm{E}$-induced asthma, we immunized these mice with a low-dose $(10 \mu \mathrm{g}$ per injection) of $B t \mathrm{E}$ instead of the $100 \mu \mathrm{g}$ dose per injection used in the previous experiments. A significantly larger number of cells was found in the BALF of the mice sensitized with low-dose of $B t E$ than in the BALF of the saline control group (Figure $5 \mathrm{~A} ; \mathrm{p}<0.01$; Student's $t$ test). Eosinophils were the main cellular type, followed by neutrophils, found in the BALF of mice of the $B t \mathrm{E}$-sensitized group, and macrophages were found in larger numbers in the saline control group (Figure 5B; $\mathrm{p}<$ 0.001 for differences in eosinophil counts between $B t E$ - sensitized and control group; Student's t test). The EPO activity was higher in the BALF of $B t E$-sensitized mice than in that of negative controls (Figure 5C; p $<0.01$; Student's $\mathrm{t}$ test). $B t \mathrm{E}$-sensitized animals had more total serum IgE as well as higher titers of anti- $B t \mathrm{E}$ IgE antibodies than the saline control group (Figure 5D and 5E; $\mathrm{p}<$ 0.05; Student's t test and Mann-Whitney's test, respectively). The effect of sensitization and challenge with 10 $\mu \mathrm{g}$ of $B t E$ per injection on lung histology is seen in Figures $5 \mathrm{~F}$ and $5 \mathrm{G}$. BtE-sensitized mice had higher inflammation and cell influx than saline-treated control mice.

\section{Discussion}

Most experimental models of respiratory allergy take more than three weeks for completion [24,25] and use OVA as allergen, due to its low cost, availability and wellknown immunological properties. However, results 


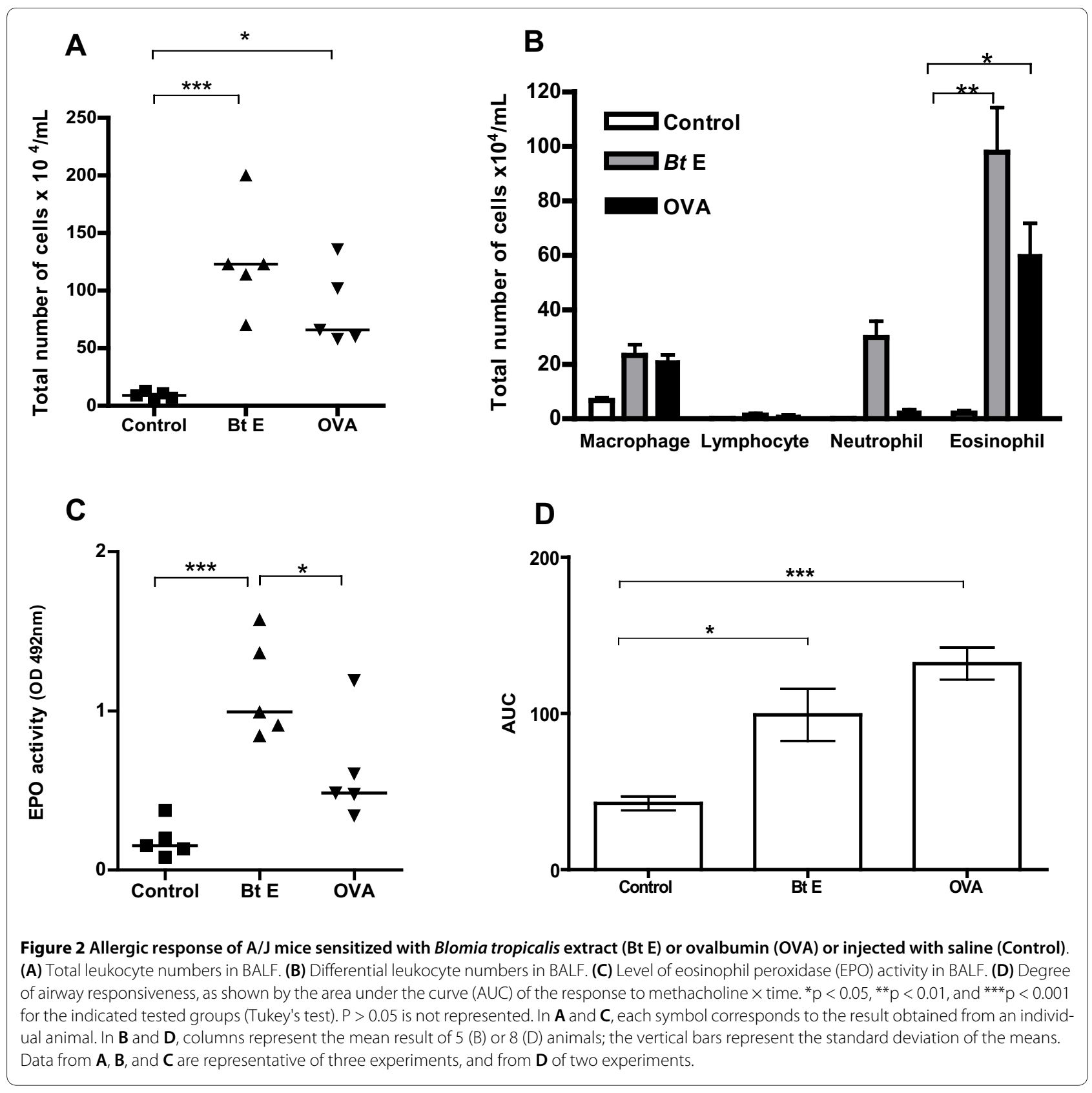

obtained in murine experimental models of respiratory allergy that use OVA as antigen differ from those obtained in experimental models using mite allergens. For instance, BALB/c mice respond vigorously to OVA in terms of allergic inflammation but are low responders to mite allergens [24]. Differences in allergenicity between $D$. pteronyssinus and $B$. tropicalis antigens have also being reported in experimental models of asthma [14]. In addition to allergen-dependent differences in intensity and nature of the allergic responses, the genetic makeup of the host seems to play an important role in murine models of respiratory allergy. On the other hand, a protocol developed by Eum and collaborators [26], using OVA, showed that shortening the duration of the allergic protocol did not affect the immunopathological features of the experimental disease, when it was compared with classical protocols [24]. It is described, herein, the development of a short-term protocol using $B$. tropicalis extract. The allergenity of $B$. tropicalis antigens to mice has been demonstrated before [14-16], although without a detailed investigation using different strains of mice and different doses of antigen. Using a short time model, we showed that $\mathrm{A} / \mathrm{J}$ mouse strain was the best responder in terms of providing an experimental model of respiratory allergy. It responded to immunization with the highest numbers of leukocytes in the BALF, consisting mainly of eosinophils, 

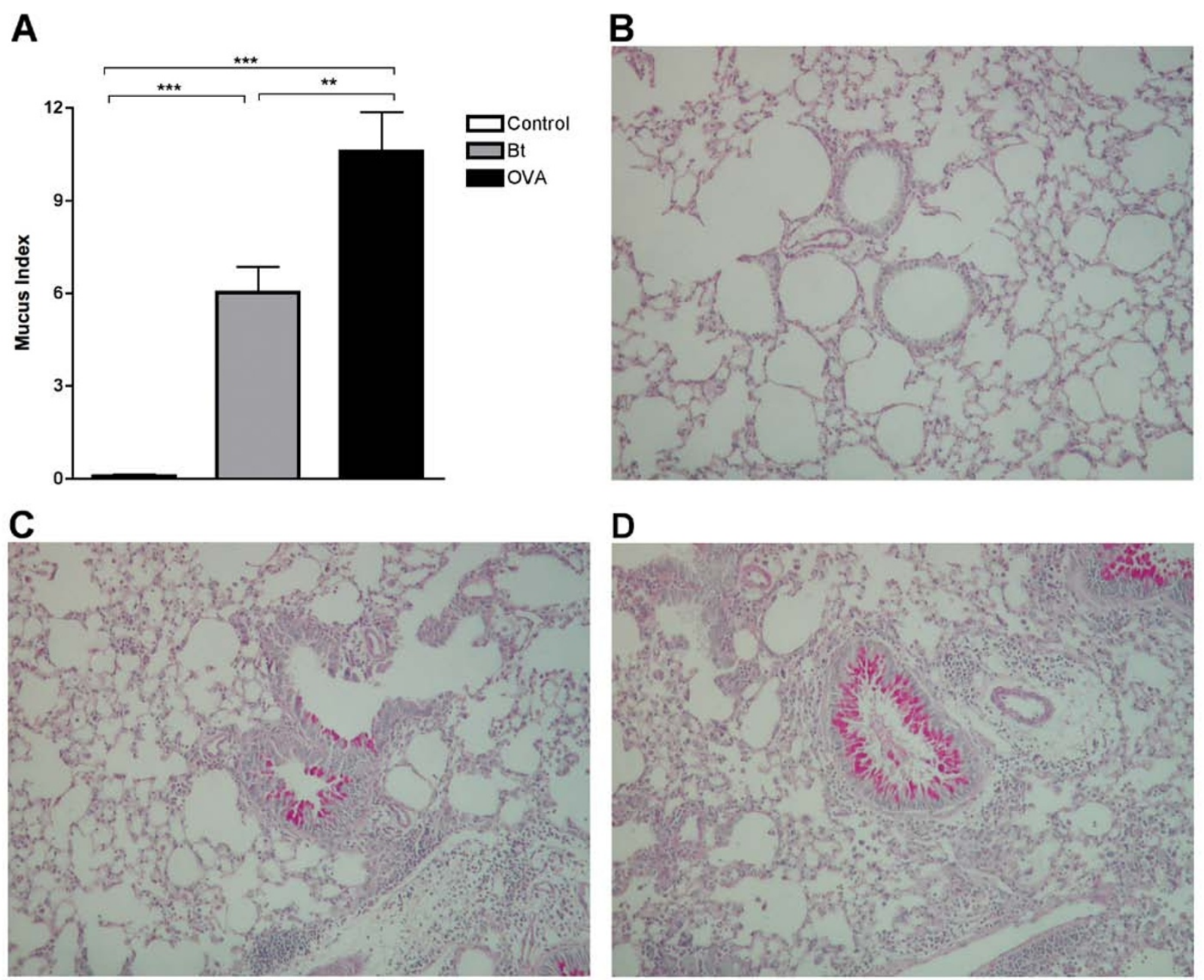

Figure 3 Presence of mucus in bronchi of $\mathrm{A} / \mathrm{J}$ mice sensitized with ovalbumin (OVA), Blomia tropicalis extract (Bt) or saline (Control). (A) Mucus Index in the bronchi. Each column represents the mean of the mucus indexes of 5 mice, and the vertical bars represent the standard deviation of the mean. ${ }^{* *} p<0.01,{ }^{* *} p<0.001$, ANOVA. (B-D) Representative lung sections stained with periodic acid-Schiff. (B) saline-injected group. (C) OVAsensitized group. (D) Bt-sensitized group. The data are representative of three independent experiments. $P>0.05$ is not represented.

and had high levels of EPO activity in the BALF. Additionally, there were high levels of IL-4 and IL-13 in BALF and increased levels of specific IgE in the sera. Finally, they had intense AHR. A/J mice were also considered the best responders to Dermatophagoides sp allergens among four studied strains [25]. Karp and collaborators [27] identified the gene encoding complement factor 5 (C5) as a susceptibility locus for allergen-induced AHR in A/J mice. This may be relevant to the human disease, as Hasegawa and collaborators have reported that polymorphism in the C3, C3a receptor, and C5 genes affect susceptibility to bronchial asthma in human beings [28].

A short-term intranasal immunization protocol with $B t E$, by itself, consisting of two intranasal instillations of $B t$ E per week, during 3 weeks, did not lead to detectable allergic responses, indicating that the subcutaneous immunization was required to induce the respiratory allergy (data not shown). This is accordance to Takeda and collaborators' observation that the intranasal instillation alone of $B t E$ elicited an IgE antibody response only when the antigen was continuously administered for a period of over 24 weeks [15]. Previous study reported that sensitization and challenge with $B t \mathrm{E}$ induce a more pronounced airway accumulation of neutrophils than eosinophils [16]. In our model, eosinophils were the preponderant cells in the airways, however similar numbers of neutrophils and eosinophils were found in airways when the animals were sensitized without alum (data not shown). Thus, it appears that alum is required to achieve fully polarized $\mathrm{Th} 2$ responses to $B t \mathrm{E}$.

Our data also indicate that results obtained with OVA sensitization cannot be extrapolated to other allergens. 

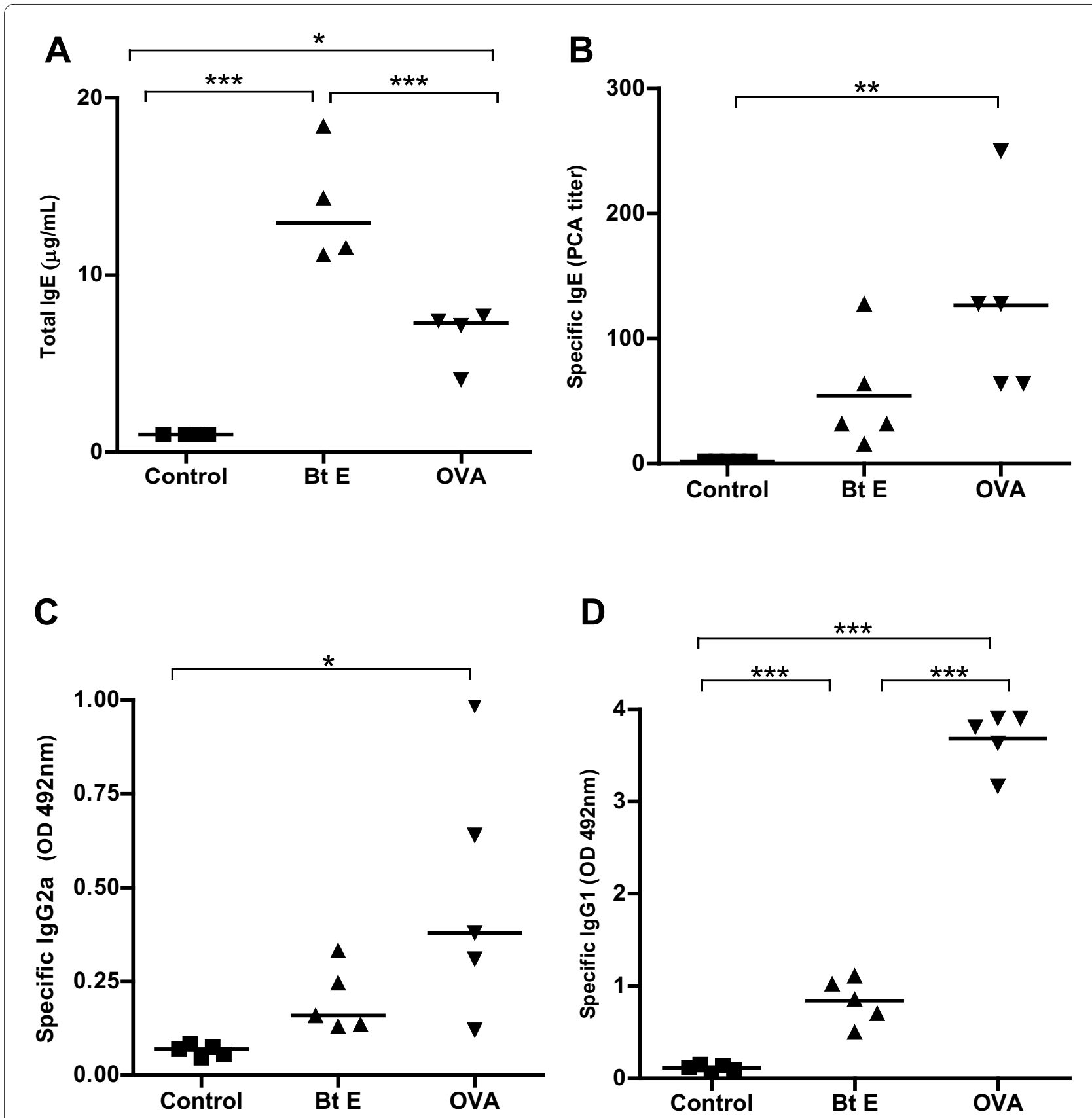

Figure 4 Total IgE and specific antibody levels in the blood of A/J mice that were sensitized with ovalbumin (OVA) or Blomia tropicalis extract (Bt E) or injected with saline (Control). (A) Total IgE. (B) Anti-Bt or anti-OVA IgE antibodies. (C) Anti-Bt or anti-OVA lgG2a antibodies. (D) AntiBt or anti-OVA lgG1 antibodies. ${ }^{*} p<0.05,{ }^{* *} p<0.01,{ }^{* * *} p<0.001$; Tukey's test. P $>0.05$ is not represented. The data are representative of three independent experiments.

Accordingly, sensitization of A/J mice to BtE led to pulmonary inflammation with eosinophil infiltrate and to total IgE increase, while OVA sensitization produced low eosinophil and IL-4 responses in this mouse strain. On the other hand, OVA sensitization led to higher mucus production, and serum levels of specific IgE, IgG1 and IgG2a than $B t$ E sensitization.
Two key mechanisms for mucus production have been identified: one activated by engagement of epidermal growth factor receptor ligands (EGFR) and the other dependent on IL-13 and STAT6 signaling [29-31]. EGFR and STAT6 signaling were not investigated in the present study, but we found increased IL-13 levels, in relation to saline-treated controls, in BtE-sensitized A/J mice. 


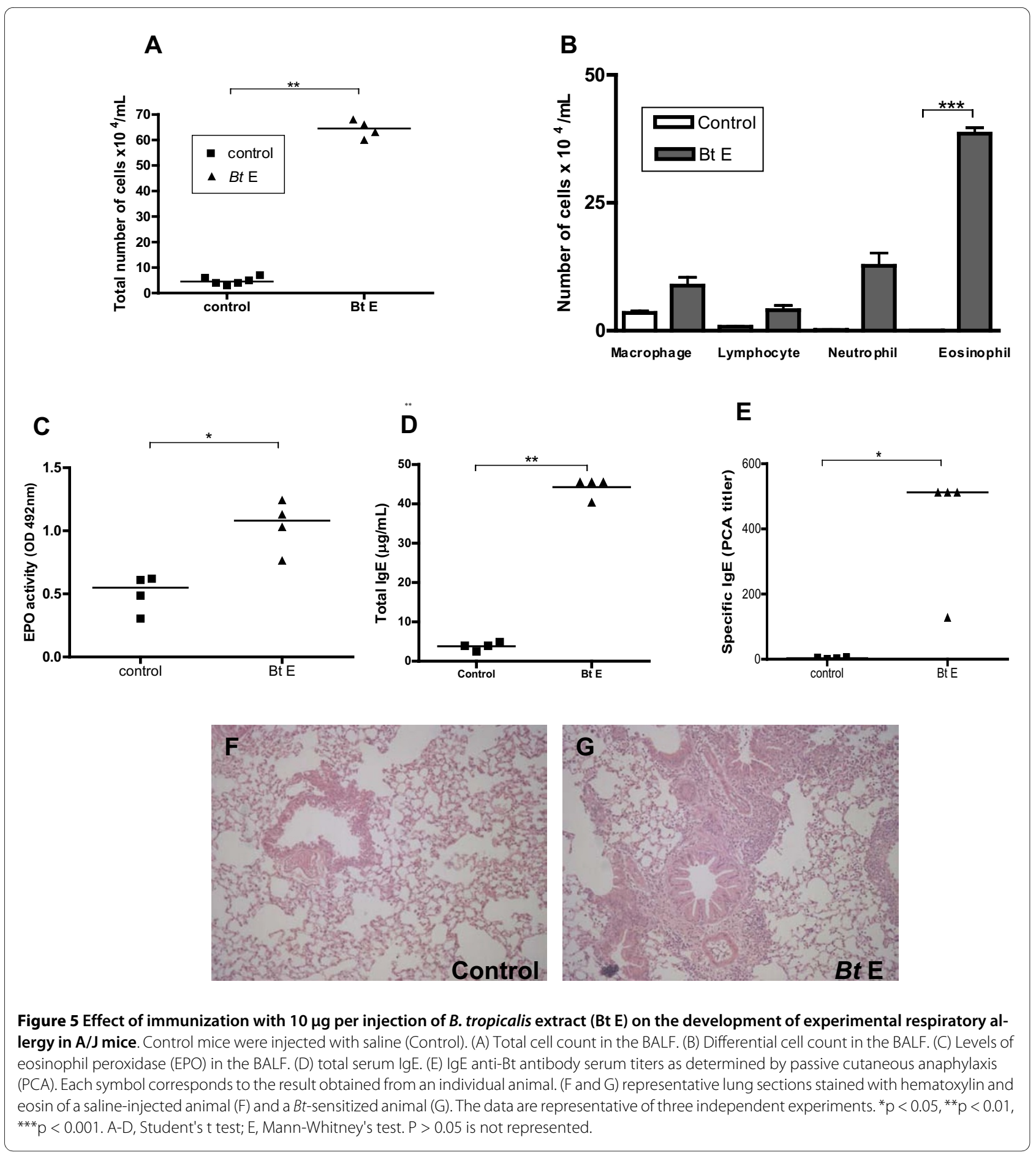

Notably, mice sensitized with $B t E$ produced higher amounts of total IgE than those sensitized with OVA, in amounts similar to those observed with immunization with helminth antigens [32]. This finding corroborated the work of Takeda and collaborators [15], who found an increase of total IgE in $B t \mathrm{E}$ - and cholera toxin- sensitized mice. Dust mite proteins, such as Blo t 11, a paramyosin from B. tropicalis that is homologue to a helminth mole- cule, is responsible for the cross-reactivity found between helminths and dust-mite species [33], and may be leading to the non-specific IgE stimulation in $B t$ E-sensitized mice found in this and in the above mentioned work. Another hypothesis is that proteases present in the $B t E$ cleave CD23, a negative regulator of IgE production [34].

Finally, we used a low dose of $B t E(10 \mu \mathrm{g} /$ per subcutaneous injection) and obtained results that were similar to 
those obtained with a high dose (100 $\mu \mathrm{g} /$ per mouse) protocol, showing that $B t \mathrm{E}$ is able to sensitize $\mathrm{A} / \mathrm{J}$ mice even at small concentrations. This model may constitute a better approximation to a natural allergenic sensitization, in which allergic individuals tend to be exposed to low allergen doses, independently of the entry route, than the so far published experimental murine models, that use higher $B t$ E doses [[14-16] and [35]].

\section{Conclusions}

Altogether, we concluded that the short-term experimental model of $B t \mathrm{E}$-induced asthma is reproducible in different mouse strains, although the A/J mice are the best responders, and small quantities of $B t E$ may be used to sensitize this mouse strain. We also concluded that a murine experimental model of respiratory allergy that uses $B t \mathrm{E}$ as allergen differs quantitatively in immunological and pathological parameters when compared with the classical experimental model that uses OVA as allergen.

\section{Abbreviations}

AHR: Airway hyperresponsiveness; BALF: Bronchoalveolar lavage fluid; BtE: Blomia tropicalis extract; EPO: Eosinophil peroxidase; IFN-ץ: Interferon gamma; IgE: Imunoglobulin E; IgG: Imunoglobulin G; IL-4: Interleukin 4; IL-10: Interleukin 10; IL-13: Interleukin 13; OVA: Ovalbumin; PBS: 0.15M phosphate-buffered saline, $\mathrm{pH}$ 7.4; PBS/BSA: PBS containing $1 \%$ of bovine serum albumin; PCA: Passive cutaneous anaphylaxis.

\section{Competing interests}

The authors declare that they have no competing interests.

\section{Authors' contributions}

TB conducted the majority of the experiments involving different mouse strains, the OVA $\times B t E$ comparison experiments and wrote the first manuscript draft. MR contributed in planning the experiments and reviewing the manuscript. VMGS, TM and PRSO helped in the experiments on different mouse strains. EG and RB helped in the experiments with OVA- and BtE-induced asthma models. ATC $L$ and CAF carried out the experiments on low dose of $B t E$. 6. LPC participated in planning the experiments and reviewing the manuscript. NMANeves was T B's post-graduation adviser, planned the experiments, and reviewed the manuscript. All authors read and approved the final manuscript.

\section{Acknowledgements}

This work was supported by the Brazilian Ministry of Science and Technology (RENORBIO programme and Conselho Nacional de Pesquisa e Desenvolvimento Tecnológico - (NPq), the Fundações de Amparo à Pesquisa dos Estados da Bahia e São Paulo (FAPESB and FAPESP), and the Wellcome Trust (Grant No. 072405/Z/03/Z)

\begin{abstract}
Author Details
'Departamento de Biointeração, Instituto de Ciências da Saúde, Universidade Federal da Bahia, Av. Reitor Miguel Calmon, Sem n. Canela, Salvador, Bahia, CEP 40110902, Brasil, 2Núcleo de Tecnologia em Saúde, Instituto Multidisciplinar em Saúde, Universidade Federal da Bahia, Av. Olívia Flores, Candeias, Vitória da Conquista, Bahia, CEP 4503100, Brazil, ${ }^{3}$ Departamento de Imunologia, Instituto de Ciências Biomédicas, Universidade de São Paulo; Av. Prof. Lineu Prestes, 1730, Cidade Universitária, Butantã, CEP 05508-900, Brazil and ${ }^{4}$ Centro de Pesquisas Gonçalo Moniz, Fundação Oswaldo Cruz, Rua Waldemar Falcão, 121, Brotas, Salvador, Bahia, CEP 40296710, Brazil
\end{abstract}

Received: 21 September 2009 Accepted: 1 May 2010 Published: 1 May 2010

\section{References}

1. Platts-Mills TAE, Chapman MD: Dust mites: immunology, allergic disease, and environmental control. J Allergy Clin Immunol 1987, 80(6):755-75

2. Platts-Mills TAE, Vervloet D, Thomas WR, Aalberse RC, Chapman MD: Indoor allergens and asthma: report of the Third International Workshop. J Allergy Clin Immunol 1997, 100(6 Pt 1):S2-24.

3. Chapman MD, Smith AM, Vailes LD, Arruda LK: Defined epitopes: in vivo and in vitro studies using recombinant allergens. Int Arch Allergy Immunol 1997, 113(1-3):102-4

4. Arruda LK, Vailes LD, Platts-Mills TAE, Fernandes-Caldas E, Montealegre F, Lin KL, Chua KY, Rizzo MC, Naspistz CK, Chapman MD: Sensitization to Blomia tropicalis in patients with asthma and identification of allergen Blo t 5. Am J Respir Crit Care Med 1997, 155(1):343-50.

5. Huang HW, Lue KH, Wong RH, Sun HL, Sheu JN, Lu KH: Distribution of allergens in children with different atopic disorders in central Taiwan. Acta Paediatr Taiwan 2006, 47(3):127-34.

6. Fernandes-Caldas E, Puerta L, Mercado D, Lockey RF: Mite fauna, Der p I, Der $\mathrm{fI}$ and Blomia tropicalis allergen levels in a tropical environment. Clin Exp Allergy 1993, 23(4):292-7.

7. Castro Almarales RL, Mateo Morejon M, Naranjo Robalino RM, Navarro Viltre BI, Alvarez Castello M, Ronquillo Diaz M, Garcia Gomez I, Oliva Diaz Y, Gonzalez Leon M, Rodriguez Canosa JS, Labrada Rosado A: Correlation between skin tests to Dermatophagoides pteronyssinus, Dermatophagoides siboney and Blomia tropicalis in Cuban asthmatics. Allergol Immunopathol (Madr) 2006, 34(1):23-6.

8. Sanchez-Borges M, Capriles-Hulett A, Caballero-Fonseca F, FernandezCaldas E: Mite and cockroach sensitization in allergic patients from Caracas, Venezuela. Ann Allergy Asthma Immunol 2003, 90(6):664-8.

9. Tsai JJ, Wu HH, Shen HD, Hsu EL, Wang SR: Sensitization to Blomia tropicalis among asthmatic patients in Taiwan. Int Arch Allergy Immunol 1998, 115(2):144-9.

10. Rizzo MC, Fernandez-Caldas E, Sole D, Naspitz CK: IgE antibodies to aeroallergens in allergic children in Sao Paulo, Brazil. J Investig Allergol Clin Immunol 1997, 7(4):242-8

11. Chew FT, Yi FC, Chua KY, Fernandes-Caldas E, Arruda LK, Chapman MD, Lee BW: Allergenic differences between the domestic mites Blomia tropicalis and Dermatophagoides pteronyssinus. Clin Exp Allergy 1999, 29(7):982-8

12. Sarpong SB, Zhang LY, Kleeberger SR: A novel mouse model of experimental asthma. Int Arch Allergy Immunol 2003, 132(4):346-54

13. Smith H: Animal models of asthma. Pulm Pharmacol 1989, 2(2):59-74.

14. Sato MN, Oliveira CR, Futata EA, Victor JR, Maciel M, Fusaro AE, Carvalho $A F$, Duarte AJ: Oral tolerance induction to Dermatophagoides pteronyssinus and Blomia tropicalis in sensitized mice: occurrence of natural autoantibodies to immunoglobulin E. Clin Exp Allergy 2002, 32(11):1667-74

15. Takeda F, Arakawa T, Toma H, Ishii A, Sato Y: Intranasal sensitization with Blomia tropicalis antigens induces allergic responses in mice characterized by elevated antigen-specific and non-specific serum $\lg \mathrm{E}$ and peripheral blood eosinophil counts. Rev Inst Med Trop Sao Paulo 2004, 46(1):1-8.

16. Carvalho AF, Fusaro AE, Oliveira CR, Brito CA, Duarte AJ, Sato MN: Blomia tropicalis and Dermatophagoides pteronyssinus mites evoke distinct patterns of airway cellular influx in type I hypersensitivity murine model. J Clin Immunol 2004, 24(5):533-41.

17. Brewer JP, Kisselgof $A B$, Martin TR: Genetic variability in pulmonary physiological, cellular, and antibody responses to antigen in mice. Am J Respir Crit Care Med 1999, 160(4):1150-6.

18. Whitehead GS, Walker JK, Berman KG, Foster WM, Schwartz DA: Allergeninduced airway disease is mouse strain dependent. Am J Physiol Lung Cell Mol Physiol 2003, 285(1):L32-42.

19. Lowry OH, Rosenbrough NJ, Faar AL, Randall RJ: Protein measurement with the folin phenol reagent. J Biol Chem 1951, 193:265-275.

20. Strath M, Warren DJ, Sanderson CJ: Detection of eosinophils using an eosinophil peroxidase assay. Its use as an assay for eosinophil differentiation factors. J Immunol Methods 1985, 83(2):209-15.

21. Keller AC, Mucida D, Gomes E, Faquim-Mauro E, Faria AMC, Rodriguez D, Russo M: Hierarchial suppression of asthma-like responses by mucosal tolerance. J Allergy Clin Immunol 2006, 117:283-290.

22. Fernvik E, Peltre G, Sénéchal H, Vargaftig BB: Effects of birch pollen and traffic particulate matter on Th2 cytokines, immunoglobulin E levels 
and bronchial hyper-responsiveness in mice. Clin Exp Allergy 2002, 32:602-611.

23. Mota I, Wong D: Homologous and heterologous passive cutaneous anaphylactic activity of mouse antisera during the course of immunization. Life Sci 1969, 15;8(16):813-20.

24. Muller E, Bergmann KC, Lachmann B, Vogel J: Experimental model of bronchial asthma. Z Erkr Atmungsorgane 1976, 144(3):246-53.

25. Yasue M, Yokota T, Suko M, Okudaira H, Okumura Y: Comparison of sensitization to crude and purified house dust mite allergens in inbred mice. Lab Anim Sci 1998, 48(4):346-52.

26. Eum SY, Hailé S, Lefort J, Huerre M, Vargaftig BB: Eosinophil recruitment into the respiratory epithelium following antigenic challenge in hyperIgE mice is accompanied by interleukin 5-dependent bronchial hyperresponsiveness. Proc Natl Acad Sci USA 1995, 92(26):12290-12294.

27. Karp CL, Grupe A, Schadt E, Ewart SL, Keane-Moore M, Cuomo PJ, Köhl J, Wahl L, Kuperman D, Germer S, Aud D, Peltz G, Wills-Karp M: Identification of complement factor 5 as a susceptibility locus for experimental allergic asthma. Nat Immunol 2000, 1(3):221-6.

28. Hasegawa K, Tamari M, Shao C, Shimizu M, Takahashi N, Mao XQ, Yamasaki A, Kamada F, Doi S, Fujiwara H, Miyatake A, Fujita K, Tamura G, Matsubara $Y$, Shirakawa T, Suzuki Y: Variations in the C3, C3a receptor, and $C 5$ genes affect susceptibility to bronchial asthma in human beings. Hum Genet 2004, 115(4):295-301.

29. Hamelmann E, Tadeda K, Schwarze J, Vella AT, Irvin CG, Gelfand EW: Development of Eosinophilic Airway Inflammation and Airway Hyperresponsiveness Requires Interleukin- 5 but Not Immunoglobulin E or B Lymphocytes. Am J Respir Cell Mol Biol 1999, 21:480-89.

30. Cohn $L$ : Mucus in chronic airway diseases: sorting out the sticky details. $\mathrm{JCl}$ 2006, 116(2):306-8

31. Farraj AK, Harkema JR, Jan TR, Kaminski NE: Immune responses in the lung and local lymph node of $\mathrm{A} / \mathrm{J}$ mice to intranasal sensitization and challenge with adjuvant-free ovalbumin. Toxicol Pathol 2003, 31(4):432-47.

32. Erb KJ: Helminths, allergic disorders and IgE-mediated immune responses: Where do we stand? Eur I Immunol 2007, 37:1170-1173.

33. Ramos JD, Cheong N, Lee BW, Chua KY: CDNA cloning and expression of Blo $\mathrm{t} 11$, the Blomia tropicalis allergen homologous to paramyosin. Int Arch Allergy Immunol 2001, 126(4):286-93.

34. Yu P, Kosco-Vilbois M, Richards M, Köhler G, Lamers MC: Negative feedback regulation of IgE synthesis by murine CD23. Nature 1994, 369(6483):753-6.

35. de Brito CA, Fusaro AE, Victor JR, Rigato PO, Goldoni AG, Muniz BP, Duarte AJS, Sato MN, Bruno : CpG-Induced Th1-Type Response in the Downmodulation of Early Development of Allergy and Inhibition of B7 Expression on T Cells of Newborn Mice. J Clin Immunol 2010.

\section{Submit your next manuscript to BioMed Central} and take full advantage of:

- Convenient online submission

- Thorough peer review

- No space constraints or color figure charges

- Immediate publication on acceptance

- Inclusion in PubMed, CAS, Scopus and Google Scholar

- Research which is freely available for redistribution

Submit your manuscript at www.biomedcentral.com/submit
C Biomed Central 